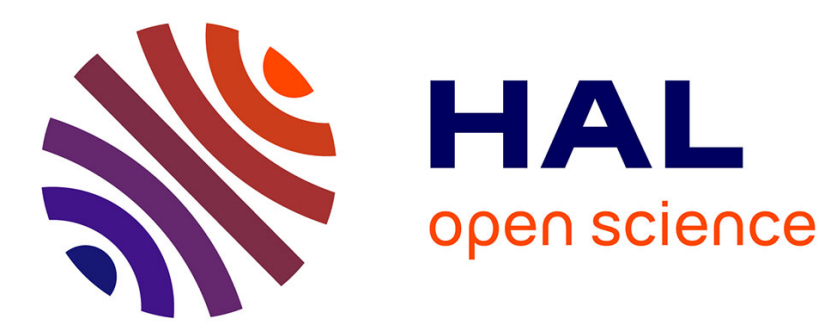

\title{
The Importance of RNA Binding Proteins in Preproinsulin mRNA Stability
}

\author{
Rikard G. Fred, Nils Welsh
}

\section{To cite this version:}

Rikard G. Fred, Nils Welsh. The Importance of RNA Binding Proteins in Preproinsulin mRNA Stability. Molecular and Cellular Endocrinology, 2008, 297 (1-2), pp.28. 10.1016/j.mce.2008.06.007 . hal-00532038

\section{HAL Id: hal-00532038 \\ https://hal.science/hal-00532038}

Submitted on 4 Nov 2010

HAL is a multi-disciplinary open access archive for the deposit and dissemination of scientific research documents, whether they are published or not. The documents may come from teaching and research institutions in France or abroad, or from public or private research centers.
L'archive ouverte pluridisciplinaire HAL, est destinée au dépôt et à la diffusion de documents scientifiques de niveau recherche, publiés ou non, émanant des établissements d'enseignement et de recherche français ou étrangers, des laboratoires publics ou privés. 


\section{Accepted Manuscript}

Title: The Importance of RNA Binding Proteins in

Preproinsulin mRNA Stability

Authors: Rikard G. Fred, Nils Welsh

PII: $\quad$ S0303-7207(08)00276-1

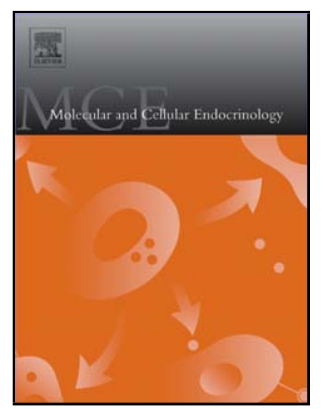

DOI: doi:10.1016/j.mce.2008.06.007

Reference: MCE 6905

To appear in: Molecular and Cellular Endocrinology

Received date:

$$
\text { 8-2-2008 }
$$

Revised date:

$$
12-6-2008
$$

Accepted date:

$12-6-2008$

Please cite this article as: Fred, R.G., Welsh, N., The Importance of RNA Binding Proteins in Preproinsulin mRNA Stability, Molecular and Cellular Endocrinology (2007), doi:10.1016/j.mce.2008.06.007

This is a PDF file of an unedited manuscript that has been accepted for publication. As a service to our customers we are providing this early version of the manuscript. The manuscript will undergo copyediting, typesetting, and review of the resulting proof before it is published in its final form. Please note that during the production process errors may be discovered which could affect the content, and all legal disclaimers that apply to the journal pertain. 


\title{
The Importance of RNA Binding Proteins in Preproinsulin mRNA Stability
}

Rikard G. Fred and Nils Welsh

Department of Medical Cell Biology, Uppsala University, Uppsala, Sweden.

Address for correspondence:

Nils Welsh, Department of Medical Cell Biology, Husargatan 3, S-75123 Uppsala, Sweden

Phone: +46-184714212, E-mail: Nils.Welsh@mcb.uu.se

key words: PTB, hnRNP I, mRNA stability, insulin gene expression, diabetes.

Abbreviations used: AMPK, AMP activated protein kinase; CSD, cold shock domain; hnRNP, heterogeneous nuclear ribonucleoprotein; mTOR, mammalian target of rapamycin; NES, nuclear export signal; NLS, nuclear localisation sequence; nPTB, neuronal PTB; PCBP, poly $(\mathrm{C})$-binding protein; PKA, protein kinase A; PTB, polypyrimidine tract-binding protein; RRM, RNA recognition motif; siRNA, small interfering RNA; SUMO, small ubiquitinrelated modifier; UTR, untranslated region.

\begin{abstract}
A dynamic production of insulin is necessary for proper glucose homeostasis. In order to generate enough insulin available for exocytosis in response to the demands of the organism, the level of preproinsulin mRNA in the pancreatic $\beta$-cell needs to fluctuate. In animal models for type 2 diabetes the contents of preproinsulin mRNA are lowered, which might suggest that an impaired metabolism of preproinsulin mRNA contributes to the development of glucose intolerance and diabetes. Thus, it is of importance to understand the mechanisms by which preproinsulin mRNA levels are regulated. Although extensively studied, there are aspects of the regulation of insulin gene expression that still remain enigmatic. Our understanding of insulin gene transcription has improved considerably the last 20 years, but less effort has been
\end{abstract}


invested into the control of preproinsulin mRNA stability. The preproinsulin mRNA has a long half-life and changes in preproinsulin mRNA stability, induced by glucose, are likely to be regulated through specific mechanisms. Recent findings indicate that the poly-pyrimidine tract binding protein (PTB), also named hnRNP I, by binding to the 3'-UTR (untranslated region) of the preproinsulin mRNA molecule, stabilizes the messenger, thereby participating in the glucose-induced increase in preproinsulin mRNA. This review will focus both on recent findings pertinent to PTB function in general, and on the specific role of PTB on the production of insulin in $\beta$-cells. We will also discuss the putative co-operativity between PTB and other proteins in the control of preproinsulin mRNA stability, and review beta-cell signaling events that may control the mRNA stabilizing effect of PTB.

\section{Insulin biosynthesis as a limiting factor in diabetes}

Diabetes mellitus is a group of metabolic disorders, which all lead to hyperglycemia through defective insulin secretion or defective insulin action. A better understanding of the relative or absolute lack of insulin, which is observed in most cases of diabetes, requires the elucidation of mechanisms that control not only insulin secretion, but also insulin biosynthesis. As an augmented insulin biosynthesis is an absolute prerequisite for extended periods of insulin hypersecretion (Ozcan et al., 2006), it is likely that disturbances in insulin biosynthesis could contribute to the insulin deficiency observed in diabetes mellitus. The rates of insulin biosynthesis are controlled by multiple mechanisms, for example by insulin gene transcription giving rise to sufficient levels of primary transcripts (Nielsen et al., 1985) and preproinsulin mRNA splicing and translation (Shalev et al., 2002). Furthermore, the capacity of the 
endoplasmic reticulum to synthesis insulin and its regulation by the unfolded protein response has attracted much attention recently (Kaneto et al., 2006). Early work from the beginning of the 1970s revealed that the rates of insulin biosynthesis are potently modulated by the surrounding concentration of glucose (Permutt and Kipnis, 1972a, Permutt and Kipnis, 1972b, Permutt, 1974). For example, a short-term (0-3 hours) glucose-induced stimulation was found to result in a pronounced increase in insulin biosynthesis rates, which did not require de novo synthesis of preproinsulin mRNA (Brunstedt and Chan, 1982; Itoh and Okamoto, 1980; Itoh et al., 1982). Furthermore, a long term glucose stimulation $(>3 \mathrm{~h})$, enhanced insulin biosynthesis even further by increasing not only the efficiency of translation, but also by inducing a specific increase in preproinsulin mRNA levels available for translation (Welsh et al., 1985). Also, preproinsulin mRNA levels are diminished in animal models for Type 2 diabetes (Giddings et al., 1982) and it is believed that glucotoxicity and lipotoxicity contribute to the worsening of beta-cell function in type 2 diabetes in part by inhibition of insulin gene expression (Poitout et al., 2006). Thus, both insulin gene expression and translational control participate in the enhanced insulin production that is required to meet a long-term increase in insulin requirement. In addition, preproinsulin mRNA levels are dictated by both insulin gene transcription and mRNA degradation rates, and these two processes has been been found to be of comparable importance for maintenance of adequate preproinsulin messenger levels (Nielsen et al., 1985, Welsh et al., 1985). A single insulin gene is present in all species but certain rodents that have two active insulin genes (Steiner et al., 1985). Although of great importance, control of transcription of the insulin gene(s) is reviewed by others and not within the scope of this paper. Instead, we will focus upon the control of preproinsulin mRNA stability and the role of PTB in this process.

\section{PTB - chromosomal localization and protein structure}

In the beginning of the 1990s polypyrimidine tracts in RNA-molecules were emerging as regulatory sites for post-transcriptional modifications. At that time PTB was identified as the heterogeneous nuclear ribonucleoprotein I (hnRNP I) (Garcia-Blanco et al., 1989; Ghetti et al., 1992), and has since then been demonstrated to participate in RNA splicing (Wagner et al., 2001), cap-independent translation (Kim et al., 2000), RNA polyadenylation (Moriera et al., 1998), RNA localization (Cote et al., 1999) and mRNA stabilization (Fred et al., 2006).

The chromosomal localization of the human PTB gene (PTBP1) is 19p13.3. The primary transcript of this gene is alternatively spliced giving rise to four transcript variants, PTBP1a PTBP1d, which are also known as PTB1, PTB2, PTB3, PTB4 and PTB-T (Gil et al., 1991; Hamilton et al., 2003; Wollerton et al., 2001). In addition, there is also a neuronal form of 
PTB (PTBP2) (Ashiya and Grabowski, 1997) and the gene coding for PTBP2 is localized to 1p22.1. It deserves to be mentioned that the several different nomenclatures for PTB can be quite confusing and sometimes misleading. For the remaining part of this review we will focuse on PTBP1, and abbreviate it as PTB.

PTB levels are controlled by an auto-regulatory feed back loop involving alternative splicing and the nonsense-mediated decay pathway (Wollerton et al., 2004). It appears that overexpression of PTB promotes a splicing pathway that results in exclusion of exon 11 and a generation of a targeting signal to the nonsense-mediated decay pathway. This pathway is responsible for the destruction of mRNAs that have either been transcribed from genes with nonsense mutations or that are incorrectly spliced. This auto-regulation may serve to prevent high levels of PTB or to restore nuclear levels during nucleocytoplasmic shuttling (Wollerton et al., 2004).

The PTB protein contains four RNA recognition motifs (RRMs). The function of the four RRMs named one through four has not been entirely understood, but RRM2 may be required for PTB oligomerization and RRM3 and RRM4 for RNA binding (Perez et al., 1997). Later reports on the structure of PTB, however, demonstrated that not only RRM3 and RRM4 bind to RNA, but that also the RRMs 1 and 2 contribute substantially to RNA binding (Simpson et al., 2004). In addition, it was observed that the full-length PTB is indeed monomeric and that all four RRMs are involved in the RNA binding. Previous indications of PTB existing as dimer in vivo have been explained as non-specific binding reactions promoted by the oxidative environment in vitro (Monie et al., 2005).

\section{PTB post-translational modification and subcellular localization}

Being a protein with important functions both in the nucleus and the cytoplasm, PTB requires signals for nucleocytoplasmic shuttling. PTB contains a nuclear export signal (NES) located to the first 25 residues of the N-terminal region, with amino acids 11-16 being the most important ( $\mathrm{Li}$ and Yen, 2002). The first 60 amino acids of the N-terminal part of both PTB and PTBP2 also contain a nuclear localization sequence (NLS) (Perez et al., 1997; Romanelli and Morandi, 2002). The PTBP2 NLS sequence has been reported to bind to the import receptor importin- $\alpha$ (Romanelli and Morandi, 2002), indicating that PTB and PTBP2 entry into the nucleus follows the classic nuclear import pathway. It has also been shown that the export of PTB, unlike other hnRNPs, is uncoupled from RNA export. Instead, the lack of binding to RNA (through deletion mutagenesis) increased the nucleocytoplasmic shuttling. Moreover, this export was energy dependent and not affected by transcription (Kamath et al., 2001). 
The nuclear export of PTB appears to occur in response to phosphorylation. The 3'-5' cAMP dependent protein kinase A phosphorylates PTB at Ser-16, which facilitates the relocalization of PTB from the nucleus to the cytoplasm (Xie et al., 2003). This was observed in HeLa and HEK 293 cells, and recent studies indicated that a similar mechanism is operational also in insulin producing cells. Here it was shown that glucose stimulated PTB phosphorylation by PKA is mediated by increased cAMP levels and that this was potentiated by the glucagon-like peptide 1. (Knoch et al., 2004; Knoch et al., 2006). In one of these studies more or less the entire pool of PTB was exported into the cytoplasm in response to stimulation with a high glucose concentration. This is a rather surprising finding that we have not been able to reproduce in our own experimental system (unpublished results). Thus, further studies are warranted for clarification of this particular point.

Sumolyation is a recently described post-translational modification, which involves the tagging of target proteins with small ubiquitin-related modifiers (SUMO). This process is quite similar to ubiquitination, but leads to altered protein function and localization rather than degradation (Melchior, 2000). It has recently been shown that hnRNP C and hnRNP M are substrates for SUMO modification. In both cases the SUMO modification occurred at the nuclear pore complexes and facilitated the nucleocytoplasmic transport of mRNA. Many other hnRNPs including PTB contain the SUMO target sequence ( $\psi \mathrm{KXE} / \mathrm{D})$, which opens the possibility that part of the nuleocytoplasmic transport of PTB is influenced by SUMO modification. SUMO modification is, however, difficult to show and not all proteins that contain the target sequence become SUMOylated (Vassileva and Matunis, 2004).

Yet another post-translational modification that might regulate PTB function is arginine methylation. Indeed, it is known that the RNA-binding activity of several hnRNP proteins is regulated by protein methylase catalyzed arginine N-methylation (Gary and Clarke, 1998). PTB is, however, methylated to a lower extent than several of the other family members (Liu and Dreyfuss, 1995), which questions the importance of this particular post-translation modification in the control of PTB activity.

\section{Control of preproinsulin mRNA levels}

The precise events that mediate increased levels of preproinsulin mRNA in response to glucose are still largely unknown. Preproinsulin mRNA is highly abundant in $\beta$-cells ranging from 20,000, at a low glucose concentration, to 100,000 molecules per cell, at a high glucose concentration (Tillmar et al., 2002). This would represent approximately 30\% of the total mRNA pool. The very high preproinsulin mRNA content of beta-cells is mainly achieved by a low turn-over rate. In a particular study, the half-life of preproinsulin mRNA was 29 hour at 
low glucose and 77 hour at high glucose (Welsh et al., 1985). Typically, both insulin gene transcription and mRNA stability are increased 2-3 fold, resulting in an approximate 5 fold increase in preproinsulin mRNA levels in response to glucose (Welsh et al., 1985). However, as de novo transcription of the insulin gene(s) contributes very little to the huge pool of preexisting mRNA molecules in the short-term, it is likely that a glucose-induced change in preproinsulin mRNA stability mediates the bulk of the increase observed the first 24 hours following stimulation (Tillmar et al., 2002).

\section{PTB and preproinsulin mRNA stability}

It is likely that there exists a group of cis-acting elements as well as trans-acting factors specifically regulating the constitutive as well as the glucose-induced stability of the preproinsulin mRNA molecule. It has been shown that both the 3' and the 5' UTR could act cooperatively in promoting glucose-induced proinsulin biosynthesis (Wicksteed et al., 2001). But more specifically, it has also been observed that the 3'-UTR of preproinsulin mRNA is critical in the control of messenger stability. The UUGAA sequence, located between the polyadenylation signal and the polyadenylation site, was suggested to be important because of its conservancy (Wicksteed et al., 2001). Alternatively, there is also a pyrimidine-rich sequence just down-stream of the termination codon and up-stream of the polyadenylation signal with similarities with the poly-pyrminidine-tract binding protein (PTB) and poly $(\mathrm{C})$ binding protein (PCBP) consensus binding sites (Tillmar et al., 2002). Indeed, PTB was recently shown to bind this sequence thereby mediating increased preproinsulin mRNA stability and levels (Tillmar et al., 2002). Interestingly, PTB has been demonstrated to bind similar pyrimidine-rich sequences located to the 3'-UTR regions of other insulin granule proteins, such as ICA512, $\mathrm{PC} 1 / 3$ and $\mathrm{PC} 2$, indicating that the biosynthesis of secretory granule proteins in general is controlled by one unifying mechanism (Knoch et al., 2004). This notion is further extended by a recent genome wide screen for functional subsets of mRNAs that associate with PTB in HeLa cells (Gama-Carvalho et al., 2006). It was observed that mRNAs belonging to the following gene ontology groups - Ubiquitin conjugation enzyme activity, Small GTPase mediated signal transduction, Intracellular protein transport, Vesicle-mediated transport, Golgi apparatus and Golgi trans face - were preferentially associated to PTB. Thus, it may be that PTB promotes stabilization of mRNAs not only coding for insulin and other insulin granule proteins, but also components comprising the entire secretory pathway. Using bioinformatic methods, it would be interesting to perform an assessment of pyrimidine rich PTB-binding consensus sequences in 3'-UTR mRNA regions of the different gene ontology groups. 


\section{PTB co-operativety with other mRNA-binding proteins}

It is generally agreed that PTB binds to the mRNA as part of a larger protein complex and there have been previous attempts to identify other proteins in this complex. Possible, but unconfirmed, candidates to be present in the PTB complex are for example hnRNP L and hnRNP C and hnRNP K (Hahm et al., 1998; Pickering et al., 2004; Irwin et al., 1997). Other candidates that might interact with PTB are the cold shock domain (CSD) containing protein, which was found in complex with PTB on vascular endothelial growth factor mRNA (Coles et al., 2004) and PSH, p54(nrb) and U1A, which bind together with PTB to the COX-2 3'UTR (Hall-Pogar et al., 2007). In addition, it has been observed that PTB bind together with La to the 3'-UTR of the Norwalk virus RNA (Gutiérrez-Escolano et al., 2003). It is therefore likely that the cooperate binding of PTB and various other RNA-binding proteins results in stabilization of the mRNAs. We have in preliminary experiments observed in vitro binding of not only PTB, but also hn RNP C, hnRNP K, hnRNP E and TiaR to preproinsulin mRNA 3'UTR (Fred et al., 2007). Both hnRNP K and hnRNP E are know to modulate mRNA stability and translation by binding to 3'-UTR regions (Messias et al., 2006), and TiaR participates in stress granule formation (Parker and Sheth, 2007). Stress granules are subcellular organelles/compartments which contain mRNAs and initiation factors that are translationally inactive. Interestingly, it has been observed that PTB and TiaR compete for RNA-binding to specific pyrimidine-rich sequences thereby achieving opposite effects on RNA-splicing (Shukla et al., 2005). It is therefore tempting to speculate that PTB and TiaR also compete for binding to the preproinsulin mRNA 3'-UTR and that when PTB binds the messenger is stabilized and used for translation, whereas if TiaR binds the mRNA, it is relocalized to stress granules and possibly also to P-bodies, organelles at which mRNAs are decapped, deadenylated and degraded (Parker and Sheth, 2007).

\section{Signals that promote PTB binding to preproinsulin mRNA}

PTB has been identified to bind to the pyrimidine-rich sequence of not only the insulin 3 ' UTR, but also other mRNAs coding for insulin granule proteins (Knoch et al., 2004). This protein/mRNA interaction is present in islets cultured at basal conditions, but can be further stimulated with a high glucose concentration or hypoxia (Tillmar and Welsh, 2002). Interestingly, the hypoxia-induced PTB/insulin 3'-UTR interaction was prevented by hydrogen peroxide (Tillmar and Welsh 2002), implicating the involvement of reactive oxygen species and/or the importance of the redox status (NADPH/GSH) for regulated PTB-activity. To closer study mechanisms of PTB activation, we recently investigated the putative 
importance of different glucose-induced signaling pathways in the control of PTB activity (Tillmar and Welsh, 2004). In this study islets incubated in the presence of rapamycin failed to induce PTB-binding in response to glucose. This was paralleled by a rapamycin-induced reduction of glucose-induced preproinsulin mRNA levels (Tillmar and Welsh, 2004). This points to the involvement of mammalian target of rapamycin (mTOR). mTOR is a phosphatidylinositol kinase-related kinase (Schmelzle and Hall, 2000), which is involved in the control of beta cell growth (Dickson et al., 2001), insulin gene transcription (Briaud et al., 2003) and insulin biosynthesis (Xu et al., 1998). Thus, it may be that not only beta-cell proliferation, insulin gene transcription and initiation of protein translation, but also preproinsulin mRNA stability are all regulated by rapamycin-sensitive pathways, suggesting a central role for mTOR as a nutrient sensor and in the regulation of beta cell function.

mTOR was recently shown to be down-regulated in response to activation of the AMPactivated protein kinase (AMPK) (Bolster et al., 2002; Kimura et al., 2003). This is a very interesting link between the cellular energy status and the mTOR pathway. AMPK is activated by an increase in the ADP/ATP ratio, caused by a decreased cellular metabolism in response to a low glucose supply or in response to cellular stress (Hardie, 1999). In addition, activated AMPK seems to inhibit glucose metabolism, insulin gene transcription and insulin secretion (da Silva Xavier et al., 2000). Considering the close link between mTOR and AMPK, it is possible that the pathway that controls preproinsulin mRNA stability in response to nutrient supply involves also AMPK. Thus, further experimentation to establish whether PTB is phosphorylated/translocated, either directly or indirectly, in response to mTOR or AMPK activation is warranted.

\section{PTB gene expression in insulin producing cells}

Islet PTB protein levels are unaffected in response to a one hour glucose stimulation (Tillmar et al., 2002). However, using a gene array approach, it has been reported that a 24-hour glucose stimulation up-regulates PTB mRNA levels in insulin producing MIN6 cells about five fold (Webb et al., 2000). More recently, we observed that a 24 hour exposure to glucose increased both preproinsulin mRNA and PTB mRNA levels (Fred and Welsh, 2005). To further test the hypothesis that PTB controls insulin gene expression, $\beta$ TC-6 cells were treated with a PTB-specific small interfering RNA sequence (siRNA) to modify the $\beta$-cell content of PTB. Surprisingly, we observed an increase in both PTB mRNA and PTB protein levels in response to the siRNA treatment. Possible explanations for this could be that the siRNA molecule, by binding to a critical region of the PTB mRNA molecule, protects, rather than promotes, against degradation, or that the siRNA molecule modulates PTB mRNA 
splicing so that a more stable mRNA is generated (Wollerton et al., 2004). In this context it is noteworthy that expression of nPTB is silenced during muscle development by a specific miRNA (miR-133) (Boutz et al., 2007). Furthermore, we also observed that the PTB-siRNA treatment of $\beta$ TC- 6 cells resulted in increased preproinsulin mRNA. These findings were interpreted to support a role of PTB in the control of preproinsulin mRNA stability and that PTB-activity is regulated over prolonged time periods by PTB gene expression.

\section{Future Perspectives}

It is now clear that the binding of PTB to preproinsulin mRNA is a complex process involving an array of different factors. Hopefully the signaling pathway that leads from increased glucose concentration to increased activity of PTB and subsequently enhanced preproinsulin mRNA stability will be better elucidated. Further goals would be to identify additional proteins that bind to the preproinsulin mRNA either in complex with PTB or by themselves. By identifying these components it is reasonable to believe that our understanding of preproinsulin mRNA stability control would be improved. This might also serve to increase our knowledge about certain forms of diabetes mellitus. For example, the chromosomal localization of the PTBP1 gene has been assigned to 19p13.3, which is a locus closely linked to Type 2 diabetes associated with the polycystic ovary syndrome (Urbanek et al., 2003). Furthermore, a model for increased insulin secretion in vivo displays signs of increased PTB binding to messengers for insulin and other secretory granule proteins (Kuwahata et al., 2007). Thus, genetic studies aiming at establishing whether any putative polymorphisms of the PTB genes associate with either Type 1 or Type 2 diabetes may be warranted.

\section{Acknowledgements}

This work was supported in part by the Swedish Research Council (12X-11564), the Swedish Diabetes Association, the family Ernfors Fund, the Novo-Nordisk Fund and the European Foundation for the Study of Diabetes.

\section{References}

Ashiya, M. and Grabowski, P.J., 1997 A neuron-specific splicing switch mediated by an array of pre-mRNA repressor sites: evidence of a regulatory role for the polypyrimidine tract binding protein and a brain-specific PTB counterpart. RNA 9, 996-1015

Bolster, D.R., Crozier, S.J., Kimball, S.R., Jefferson, L.S., 2002. AMP-activated protein kinase suppresses protein synthesis in rat skeletal muscle through down- 
regulated mammalian target of rapamycin (mTOR) signaling. J Biol Chem 277, 23977-23980

Briaud, I., Lingohr, M.K., Dickson, L.M., Wrede, C.E., Rhodes, C.J., 2003 Differential activation mechanisms of Erk-1/2 and p70(S6K) by glucose in pancreatic betacells. Diabetes 52, 974-983

Brunstedt, J., Chan, S.J., 1982 Direct effect of glucose on the preproinsulin mRNA level in isolated pancreatic islets. Biochem Biophys Res Commun 106, 1383-1389

Boutz, P.L., Chawla, G., Stoilov, P., Black, D.L., 2007 MicroRNAs regulate the expression of the alternative splicing factor nPTB during muscle development. Genes Dev 21, 71-84

Coles, L.S., Bartley, M.A., Bert, A., Hunter, J., Polyak, S., Diamond, P., Vadas, M.A., Goodall, G.J., 2004 A multi-protein complex containing cold shock domain (Ybox) and polypyrimidine tract binding proteins forms on the vascular endothelial growth factor mRNA. Eur J Biochem 271, 648-660

Cote, C.A., Gautreau, D., Denegre, J.M., Kress, T.L., Terry, N.A., Mowry, K.L., 1999 A Xenopus protein related to hnRNP I has a role in cytoplasmic RNA localization. Mol. Cell 4, 431-437

da Silva Xavier, G., Leclerc, I., Salt, I.P., Doiron, B., Hardie, D.G., Kahn, A., Rutter, G.A., 2000 Role of AMP-activated protein kinase in the regulation by glucose of islet beta cell gene expression. Proc Natl Acad Sci USA 97, 4023-4028

Dickson, L.M., Lingohr, M.K., McCuaig, J., Hugl, S.R., Snow, L., Kahn, B.B., Myers, M.G. Jr, Rhodes, C.J., 2001 Differential activation of protein kinase B and p70(S6)K by glucose and insulin-like growth factor 1 in pancreatic beta-cells (INS-1). J Biol Chem 276, 21110-21120

Fred, R.G., Adams, C.M., Welsh, N., 2007 Affinity binding analysis shows that hnRNP K and hnRNP E, in cytosolic extracts from human islets, binds specifically to the stabilizing segment of insulin mRNA. Diabetologia 50, S207, Suppl: 1

Fred, R., Tillmar, L., Welsh, N., 2006 The role of PTB in insulin mRNA stability control. Curr Diabetes Rev 2, 363-366

Fred, R.G., Welsh, N., 2005 Increased expression of polypyrimidine tract binding protein results in higher insulin mRNA levels. Biochem Biophys Res Commun 328, $38-42$

Gama-Carvalho, M., Barbosa-Morais, N.L., Brodsky, A.S., Silver, P.A., Carmo-Fonseca, M., 2006 Genome-wide identification of functionally distinct subsets of cellular mRNAs associated with two nucleocytoplasmic-shuttling mammalian splicing factors. Genome Biol 7: R113

Garcia-Blanco, M. A., Jamison, S.F., Sharp, P.A., 1989 Identification and purification of a 62,000-dalton protein that binds specifically to the polypyrimidine tract of introns. Genes Dev 12A, 1874-1886

Gary, J.D., Clarke, S., 1998 RNA and protein interactions modulated by protein arginine methylation. Proc Nucleic Acid Res Mol Biol 61, 65-131

Ghetti, A., Piñol-Roma, S., Michael, W., Morandi, C., Dreyfuss, G., 1992 hnRNP I, the polypyrimidine tract-binding protein: distinct nuclear localization and association with hnRNAs. Nucleic Acids Res 20, 3671-3678

Giddings, S.J., Chirwin, J., Permutt, A., 1982 Effects of glucose on proinsulin messenger RNA in rats in vivo. Diabetes 31, 624-629

Gil, A., Sharp, P.A., Jamison, S.F., Garcia-Blanco, M.A., 1991 Characterization of cDNAs encoding the polypyrimidine tract-binding protein. Genes Dev.7, 1224-36.

Gutiérrez-Escolano, A.L., Vázquex-Ochoa, M., Escobar-Herrera, J., Hernández-Acosta, J., $2003 \mathrm{La}, \mathrm{PTB}$, and PAB proteins bind to the 3(') untranslated region of Norwald virus genomic RNA. Biochem Biophys Res Commun 311, 759-766 
Hahm, B., Cho, O.H., Kim, J.E., Kim, Y.K., Kim, J.H., Oh, Y.L., Jang, S.K., 1998 Polypyrimidine tract-binding protein interacts with HnRNP L. FEBS Lett 425, 401-406.

Hall-Pogar, T., Liang, S., Hague, L.K., Lutz, C.S., 2007 Specific trans-acting proteins interact with auxillary RNA polyadenylation elements in the COX-2 3'-UTR. RNA 13, $1103-1115$

Hamilton, J.B., Genin, A., Cron, R.Q., Rigby, F.C., 2003 Delineation of a novel pathway that regulates CD154 (CD40 Ligand) Expression. Mol. Cell. Biol. 23, 510-525

Hardie, D.G., 1999 Roles of the AMP-activated/SNF1 protein kinase family in the response to cellular stress. Biochem Soc Symp 64, 13-27

Irwin, N., Baekelandt, V., Goritchenko, L., Benowitz, L.I., 1997 Identification of two proteins that bind to a pyrimidine-rich sequence in the 3'-untranslated region of GAP-43 mRNA. Nucleic Acids Res. 25, 1281-8.

Itoh, N., Okamoto, H., 1980 Translational control of proinsulin synthesis by glucose. Nature 283, 100-102.

Itoh, N., Ohshima, Y., Nose, K., Okamoto, H., 1982 Glucose stimulates proinsulin synthesis in pancreatic islets without a concomitant increase in proinsulin mRNA synthesis. Biochem Int 4, 315-321

Kamath, R.V., Leary, D.J., Huang, S., 2001 Nucleocytoplasmic shuttling of polypyrimidine tract-binding protein is uncoupled from RNA export. Mol Biol Cell 12, 38083820

Kaneto, H., Nakatani, Y., Kawamori, D., Miyatsuka, T., Matsuoka, T.A., Matsuhisa, M., Yamasaki, Y., 2006 Role of oxidative stress, endoplasmic reticulum stress, and c-Jun N-terminal kinase in pancreatic beta-cell dysfunction and insulin resistance. Int J Biochem Cell Biol 38, 782-793

Kim, Y.K., Hahm, B., Jang, S.K., 2000 Polypyrimidine tract-binding protein inhibits translation of bip mRNA. J Mol Biol 304, 119-133

Kimura, N., Tokunaga, C., Dalal, S., Richardson, C., Yoshino, K., Hara, K., Kemp, B.E., Witters, L.A., Mimura, O., Yonezawa, K., 2003 A possible linkage between AMP-activated protein kinase (AMPK) and mammalian target of rapamycin (mTOR) signalling pathway. Genes Cells 8, 65-79

Knoch, K-P., Bergert, H., Borgonovo, B., Saeger, H.D., Altkrüger, A., Verkade, P., Solimena, M., 2004 Polypyrimidine tract-binding protein promotes insulin secretory granule biogenesis. Nat Cell Biol 6, 207-214

Knoch, K.P., Meisterfeld, R., Kersting, S., Bergert, H., Altkrüger, A., Wegbrod, C., Jäger, M., Saeger, J.D., Solimena, M., 2006 cAMP-dependent phophorylation of PTB1 promotes the expression of insulin secretory granule proteins in beta cells. Cell Metabolism 3, 123-134

Kuwahata, M., Tomoe, Y., Harada, N., Amano, S., Segawa, H., Tatsumi, S., Ito, M., Oka, T., Miyamoto, K., 2007 Characterization of the molecular mechanisms involved in the increased insulin secretion in rats with acute liver failure. Biochim Biophys Acta 1772, 60-65

Li, B., Yen, T.S.B., 2002 Characterization of the nuclear export signal in polypyrimidine tract-binding protein. J Biol Chem 277, 10306-10314

Liu, Q., Dreyfuss, G., 1995 In vivo and in vitro arginine methylation of RNA-binding proteins. Mol Cell Biol 15, 2800-2808

Melchior, F., 2000 SUMO-nonclassical ubiquitin. Annu Rev Cell Dev. Biol 16, 591-626

Messias, A.C., Harnisch, C., Ostareck-Lederer, A., Sattler, M., Ostareck, D.H., 2006 The DICE-binding activity of KH domain 3 of hnRNP K is affected by c-Srcmediated tyrosine phosphorylation. J Mol Biol 361, 470-481

Monie, T.P., Hernandez, H., Robinson, C.V., Simpson, P., Matthews, S., Curry, S., 2005 The polypyrimidine tract binding protein is a monomer. RNA 11, 1803-1808 
Moreira, A., Takagaki, Y., Brackenridge, S., Wollerton, M., Manley, J.L., Proudfoot, N.J., 1998 The upstream sequence element of the C2 complement poly(A) signal activates mRNA 3' end formation by two distinct mechanisms. Gene Dev 12, 2522-2534

Nielsen, D.A., Welsh, M., Casadaban, M.J., Steiner, D.F., 1985 Control of insulin gene expression in pancreatic beta-cells and in an insulin-producing cell line, RIN-5F cells. I. Effects of glucose and cyclic AMP on the transcription of insulin mRNA. J Biol Chem 260, 13585-13589

Ozcan, U., Yilmaz, E., Ozcan, L., Furuhashi, M., Vaillancourt, E., Smith, R.O., Görgün, C.Z., Hotamisligil, G.S., 2006 Chemical chaperones reduce ER stress and restore glucose homeostasis in a mouse model of type 2 diabetes. Science 313,1137 1140

Parker, R., Sheth, U., 2007 P bodies and the control of mRNA translation and degradation. Mol. Cell 25, 635-645

Perez, I., Lin, C.H., McAfee, J.G., Patton, J.G., 1997 Mutation of PTB binding sites causes misregulation of alternative 3 ' splice site selection in vivo. RNA 3, 764-78.

Permutt, M.A., 1974 Effect of glucose on initiation and elongation rates in isolated rat pancreatic islets. J Biol Chem 249, 2738-2742

Permutt, M.A,, Kipnis, D.M., 1972 Insulin biosynthesis. II. Effect of glucose on ribonucleic acid synthesis in isolated rat islets. J Biol Chem 247, 1200-1207

Permutt, M.A., Kipnis, D.M., 1972 Insulin biosynthesis. I. On the mechanism of glucose stimulation. J Biol Chem 247, 1194-1199

Pickering, B.M., Mitchell, S.A., Spriggs, K.A., Stoneley, M., Willis, A.E., 2004 Bag-1 internal ribosome entry segment activity is promoted by structural changes mediated by poly $(\mathrm{rC})$ binding protein 1 and recruitment of polypyrimidine tract binding potein 1. Mol Cell Biol 24, 5595-5605

Poitout, V., Hagman, D., Stein, R., Artner, I., Robertson, R.P., Harmon, J.S., 2006 Regulation of the insulin gene by glucose and fatty acids. J Nutr 136, 873-876

Rahman, L., Bliskovski, V., Reinhold, W., Zajac-Kaye, M., 2002 Alternative splicing of brain-specific PTB defines a tissue-specific isoform pattern that predicts distinct functional roles. Genomics 80, 245-9.

Romanelli, M.G., Morandi ,C., 2002 Importin alpha binds to an unusual bipartite nuclear localization signal in the heterogeneous ribonucleoprotein type I. Eur J Biochem 269, 2727-2734

Schmelzle, T., Hall, M.N., 2000 TOR, a central controller of cell growth. Cell 103, 253-262

Shalev, A., Blair, P.J., Hoffmann, S.C., Hirshberg, B., Peculis, B.A., Harlan, D.M., 2002 A proinsulin gene splice variant with increased translation efficiency is expressed in human pancreatic islets. Endocrinology 143, 2541-7

Shukla, S., Del Gatto-Konczak, F., Breathnach, R., Fisher, S.A., 2005 Competition of PTB with TIA proteins for binding to a U-rich cis-element determines tissue-specific splicing of the myosin phosphatase targeting subunit 1. RNA 11, 1725-1736

Simpson, P.J., Monie, T.P., Szendröi, A., 2004 Structure and RNA interactions of the Nterminal RRM domains of PTB. Structure 13, 1631-1643

Steiner, D.F., Chan, S.J., Welsh, J.M., Kwok, S.C.M., 1985 Structure and evolution of the insulin gene. Annu Rev Genet 19, 463-484

Tillmar, L., Carlsson, C., Welsh, N., 2002 Control of insulin mRNA stability in rat pancreatic islets. J Biol Chem 277, 1099-1106

Tillmar, L., Welsh, N., 2002 Hypoxia may increase rat insulin mRNA levels by promoting binding of the polypyrimidine tract-binding protein (PTB) to the pyrimidine-rich insulin mRNA 3'-untranslated region. Mol Med 8, 263-272 
Tillmar, L., Welsh, N., 2004 Glucose-induced binding of the polypyrimidine tract-binding protein (PTB) to the 3'-untranslated region of the insulin mRNA (ins-PRS) is inhibited by rapamycin. Mol Cell Biochem 260, 85-90

Urbanek, M., Du, Y., Silander, K., Collins, F.S., Steppan, C.M., Strauss, J.F. 3rd, Dunaif, A., Spielman, R.S., Legro, R.S., 2003 Variation in resistin gene promoter not associated with polycystic ovary syndrome. Diabetes 52, 214-217

Vassileva, M.T., Matunis, M.J., 2004 SUMO modification of heterogeneous nuclear ribonucleoproteins. Mol Cell Biol 24, 3623-3632

Wagner, E.J., Garcia-Blanco, M.A., 2001 Polypyrimidine tract binding protein antagonizes exon definition. Mol Cell Biol 21, 3281-3288

Webb, G.C., Akbar, M.S., Zhao, C., Steiner, D.F., 2000 Expression profiling of pancreatic beta cells: Glucose regulation of secretory and metabolic pathway genes. Proc Natl Acad Sci USA 97, 5773-5778

Welsh, M., Nielsen, D.A., MacKrell, A.J., Steiner, D.F., 1985 Control of insulin gene expression in pancreatic beta-cells and in an insulin-producing cell line, RIN5F cells. J Biol Chem 260, 13590-13594

Wicksteed, B., Herbert, T.P., Alarcon, C., Lingohr, M.K., Moss, L.G., Rhodes, C.J., 2001 Cooperativity between the preproinsulin mRNA untranslated region is necessary for glucose-stimulated translation. J Biol Chem 276, 22553-22558

Wollerton, M.C., Gooding, C., Robinson, F., Brown, E.C., Jackson, R.J., Smith, C.W., 2001 Differential alternative splicing activity of isoforms of polypyrimidine tract binding protein (PTB). RNA 7, 819-32.

Wollerton, M.C., Gooding, C., Wagner, E.J., Garcia-Blanco, M.A., Smith, C.W.J. 2004 Autoregulation of polypyrimidine tract binding protein by alternative splicing leading to nonsense-mediated decay. Mol Cell 13, 91-100

Xie J, Lee J-A, Kress TL, Mowry KL, Black DL., 2003 Protein kinase A phosphorylation modulates transport of the polypyrimidine tract-binding protein. Proc Natl Acad Sci USA 100, 8776-81

Xu G, Marshall, C.A., Lin, T.A., et al., 1998 Insulin mediates glucose-stimulated phosphorylation of PHAS-I by pancreatic beta cells. An insulin-receptor mechanism for autoregulation of protein synthesis by translation. J Biol Chem $273,4485-4491$ 


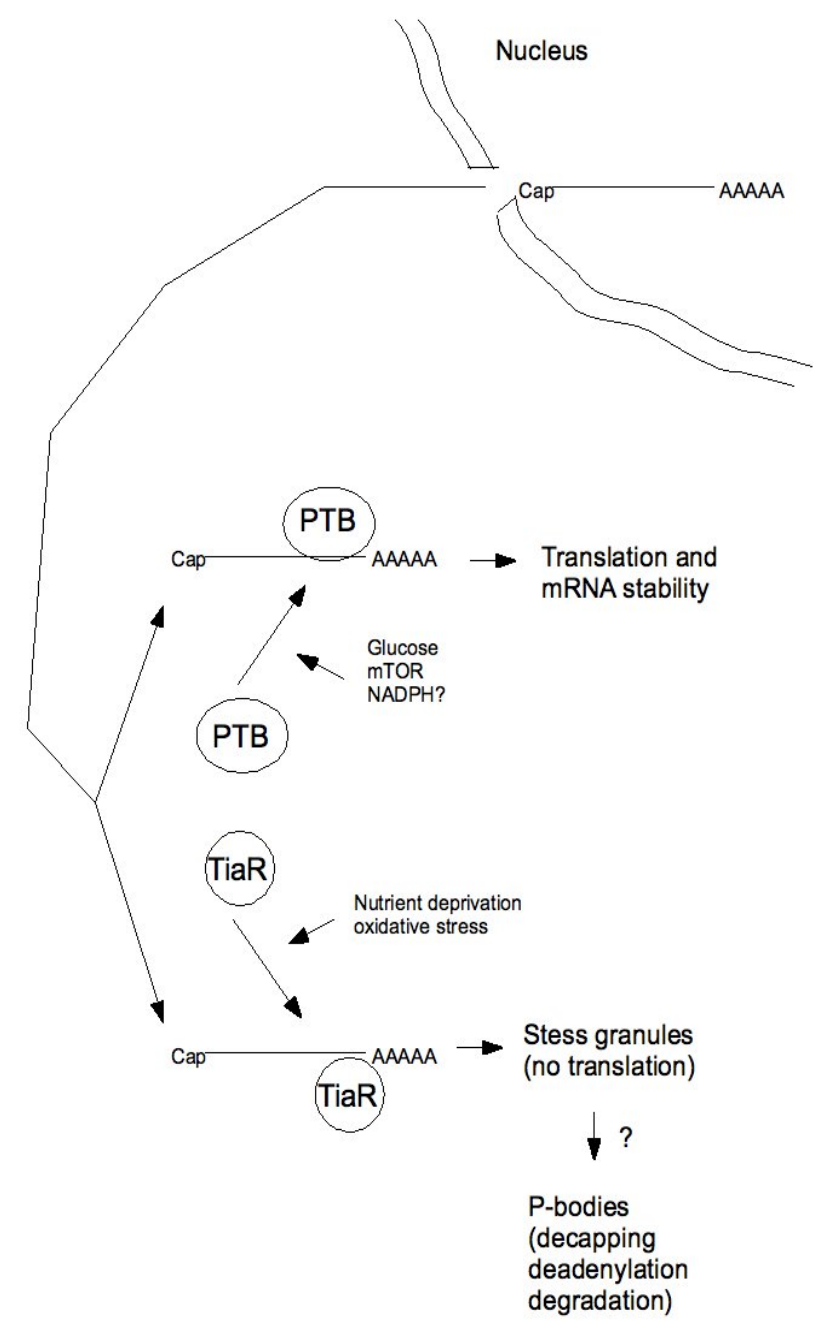

Figure 1. Hypothetical model for control of preproinsulin mRNA stability in insulin producing cells. PTB binds, probably together with other proteins, the 3'-UTR of preproinsulin mRNA, which leads to stabilisation and translation of the messenger. This event is stimulated by glucose and the effect of nutrients may be mediated by mTOR and possibly also the cytosolic reduction potential (NADPH). On the other hand, nutrient deprivation and other forms of stress may promote binding of TiaR to the same 3'-UTR region, which removes the mRNA from active translation and moves it on to degradation via stress granules and P-bodies. 